\title{
(Non) Art in the Art of Advertising
}

\section{Sibila Petenji Arbutina and Jelena Kovačević Vorgučin The Higher Technical School of Professional Education, Novi Sad, Serbia}

\author{
sibila.petenji.arbutina@gmail.com jelka.photo@gmail.com
}

\begin{abstract}
This paper sets out to point to the manner of presenting art in a society, as well as to the manner of fulfilling cultural needs and ways of developing and encouraging these needs. The paper also deals with the extent to which an advertising campaign is capable of realizing its ideas, its limitations and ways in which an idea is modified to suit the needs.

Special attention is paid to types of communication through art and design and also to the flow of information between a producer and consumer through outdoor advertising. We deal with presentation of art through advertising campaign and point to alternative types of advertising. We also analyse to what extent politics, economy and social aspects influence the development of advertising in a culturally underdeveloped environment.
\end{abstract}

Key words: presentation of art, cultural needs, communication through art, cultural education, unconventional expression

\section{Introduction}

This paper deals with presentation of information through outdoor advertising, which as a direct communication medium provokes an immediate reaction of the public. We shall explain the cultural management aims that are of immense importance for the planning of the cultural needs of a society, which is an indispensable factor for raising public awareness and making the public enter into a dialogue.

We will point to the ways of achieving a successful advertising which meets the needs of almost every target group. The emphasis is on the reaction of the public: it is not of crucial importance whether its reaction is positive or negative. The important thing is not to have an indifferent reaction. What we consider to be the main aim of advertising is not only to notice, but also to remember and emotionally react to a particular advertising message.

We pay special attention to the problem of establishing communication through advertising campaigns in our country, where the presentatoin of art has been neglected for several decades as the

Material published as part of this publication, either on-line or in print, is copyrighted by the Informing Science Institute. Permission to make digital or paper copy of part or all of these works for personal or classroom use is granted without fee provided that the copies are not made or distributed for profit or commercial advantage AND that copies 1) bear this notice in full and 2) give the full citation on the first page. It is permissible to abstract these works so long as credit is given. To copy in all other cases or to republish or to post on a server or to redistribute to lists requires specific permission and payment of a fee. Contact Publisher@InformingScience.org to request redistribution permission. country was closed to culture due to various crises brought about by political issues.

We will show some ways of exhibiting advertisements, influence of the ambience on their noticeability and the use of space as an integral part of an advertisement. 


\section{Cultural Management}

Cultural management deals with culture as a system within which direct human activities enable setting out of the conditions for cultural and especially art creativity, as well as the forms of its presenting and acceptance by the general public (Gidens, 2005). If such activities are to be successfully conducted in a society, it is necessary to perceive cultural needs of the general public.

The fundamental task of a culture manager is to research and recognize cultural needs with an aim of planning cultural activities and programmes (for fulfilment of cultural needs), and thus at the same time to plan the cultural development of a society.

\section{Cultural Needs}

What is meant by cultural needs is both basic needs for linguistic expression and communication as well as the need for learning, i.e. for broadening the mind, then the need for beauty in everyday life and, of course, need for aesthetic experience and creativity represented by fine art forms (drawing, painting, sculpture etc.)

The institutions established by the society have a key role in the process of developing cultural needs, but a family or background have a significant impact on development and bringing up of an individual. Therefore, the expansion and adoption of cultural needs might be spontaneous or organized but this process is undoubtedly influenced by:

- Cultural atmosphere of the family life

- Local community and peer groups

- Institutional forms (1. Schools, 2. Libraries, archives etc. and 3. Museums, galleries, theatres, concert halls)

- Mass media: radio, cable and satellite TV, newspapers, the Internet presentations, classic media (newspapers) digitized into online editions, digitized libraries, online entertainment, films, music and music videos. (Dragicevic Sesic, \& Stojkovic, 2007).

- The authors consider that the outdoor advertising also has a great impact in all its forms and it is sometimes accepted on the subconscious level, without thinking.

More and more often audience is seen not as a mere passive object, but a subject that has a possibility of interactive participation. The extent to which an individual would fulfill and upgrade his/her cultural needs depends on his/her activities on internet forums, in blogs, on direct involvement in particular projects or portals of culture which enable easier search for information about authors, works of art and cultural projects.

"If we take into account that 'surfing' by means of a remote controller leads to the situation where the audience creates its own virtual mosaic, we can realize that the media have become globally connected because the programme and messages are transmitted through world network, but we can also see that a man of modern society does not live in a global village, but in his/her interests..." (Dragicevic Sesic \& Stojkovic, 2007).

We believe that examining of the power of a spectacle as the moment of propaganda and economy, researching into reactions of the audience regarding (non)acceptance of the message, examining the levels of collective consciousness, as well as pointing to the possible ambiguity in the message, are significant requirements for the advancement in the visual information.

In any case, we insist that knowledge is an indispensable condition for acceptance or nonacceptance of particular visual information, as well as a condition for presentation and understanding of a creative idea. 


\section{Aesthetic Needs in Everyday Life}

A man's primal urge for visual expression is perceived in a child's first impulse of creativity when one-year old children express themselves through painting, drawing and shaping. Rapid development of aesthetic needs in everyday life has led to implementation of the visual arts into our daily life. The needs for taking care of our environment (home, working environment) and also of our personalities by means of make-up and hair-style have had an impact on development of fine and applied art as two closely related forms that are more often called the visual arts nowadays. The original concept comprising painting, sculpture and graphic art has extended its expression to include applied art as well.

The twentieth century is marked by the development of design and its use in every field of production, from culture industry products (books, CD-ROMs) to consumer goods (toiletries, electronic devices etc.). In the modern world of fashion and consumption of mass culture, there is an ever-increasing need for placement of new types of products, and there is also necessity to increase demand in order to increase purchase - consumption. Applied art and design have become an inseparable part of our everyday life, and thus they have taken their place among the visual arts: architecture (which creates style and design of a town, flat), sculpture and installations in public places / public arts, painting (comics, mural, graffiti), graphic art and graphic design, video and digital arts, the Internet (web art), the press and magazines, and especially the art of advertising.

Regarding advertising, the way in which an idea is presented is of crucial importance as well as the post-production which is nowadays considered important both in cultural education and for generating profit. The way in which information is presented, what it implies, what kind of message it should convey and what are the limitations of its production are the factors that do matter and therefore we will deal with the diffusion of a fine art work further on.

\section{Diffusion of Fine Art Works}

The exhibition as a basic form of the diffusion of works of fine art, depending on their character, idea, informative level they contain, purpose and other factors, has to be adapted to the space where it is presented. Museums (retrospective and other larger exhibitions), art galleries, commercial galleries, gallery space of cultural centres and other non-profit institutions, gallerybookshops or café-gallery, gallery-shops, gallery space in companies: factories, banks etc, as well as restaurants, shops, faculty lounges and other space which is not specially designed for exhibition purposes ... are some examples of the closed type of exhibition space. Open public space like streets, parks, and promenade more and more often become public galleries where lots of people gather as they are easily accessible. The $21^{\text {st }}$ century brings about some radical changes to the presentation of fine art. Today, the art is presented in new, original or "different places" in order to have the information transmitted to consumers as fast as possible and to attract attention through being a "novelty".

We believe that the impact of outdoor advertising campaigns is directly connected to the presentation of art in out-of-gallery space. The race for profit tries to create links between an advertising product and fine arts. It is the fact that such campaigns, which do not only convey direct information but use a pure creativity of thought and a good idea for product sale, meet both the economic and aesthetic requirements and raise the public cultural awareness.

In view of the fact that information is rapidly shared in the modern society and there is the need for speed reading and understanding, presentation of art through advertising is, from our point of view, an ideal solution. 
Technological and technical inventions enable arts to be presented in modern ways. Thus street billboards, in addition to advertising campaigns of highly informative and aesthetic value, often show fine art exhibitions.

Art makes use of exhibition advertising principles (see Figure 1), while pure art as a basic idea that sells the product is ever-increasingly present in the production of advertising (see Figures 2 and 3).

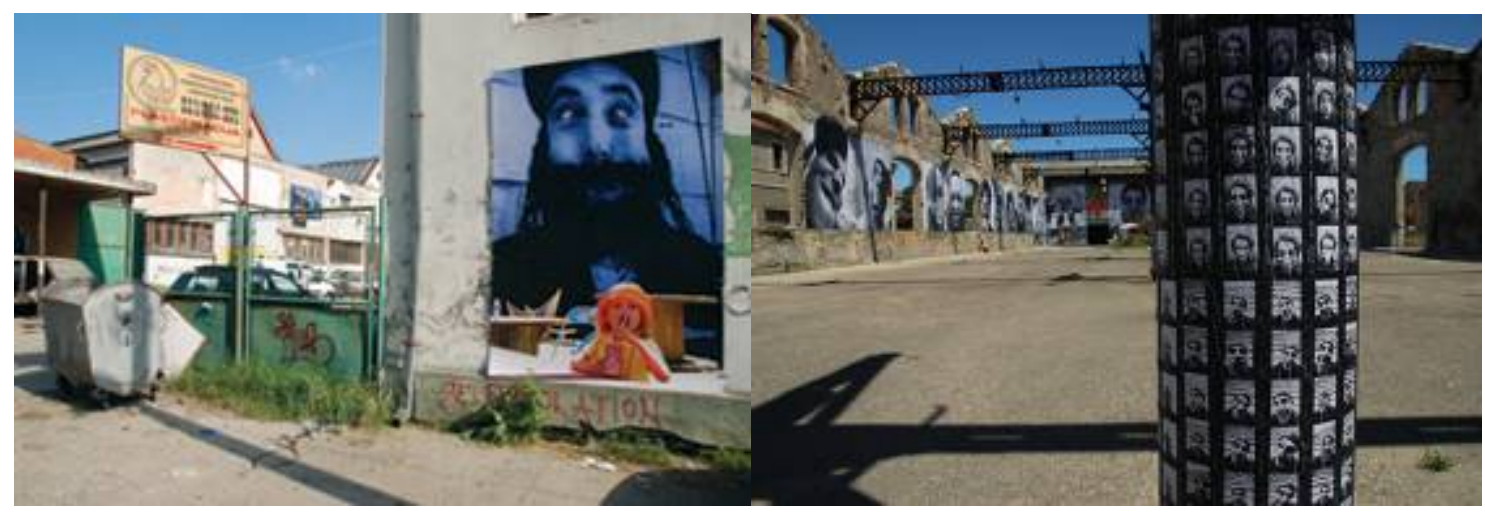

Figure 1. Examples of the Art exhibitions in the Open Air Source: Personal source

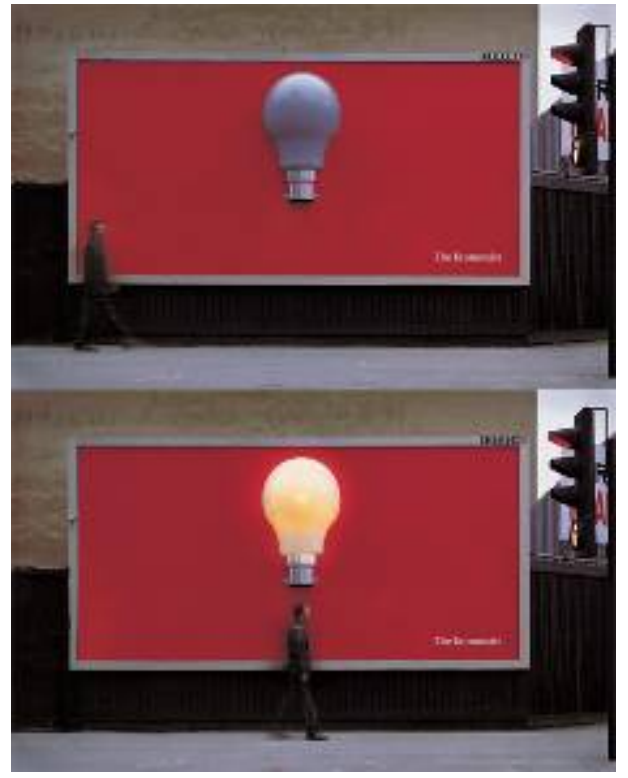

Figure 2. Example of the Creative Billboard Source: http://enso.com.au/move-intooutdoor-advertising/

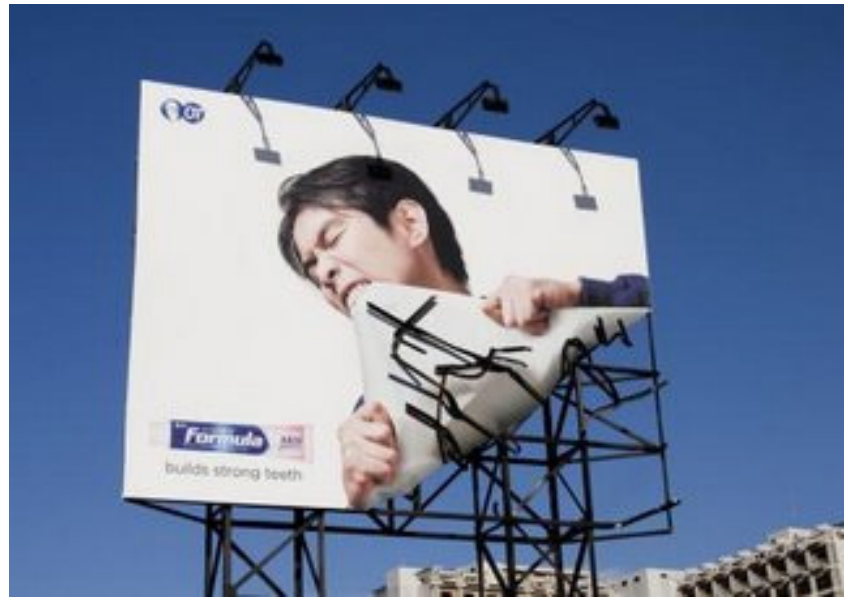

Figure 3. Example of the Creative Billboard Source:

http://www.thebillboardawards.com/pervertedbillboard/

\section{Outdoor Advertising}

Further on in the paper, we would like to point to the advantages of outdoor advertising. 
We believe that large-formats of outdoor advertising such as, for example, billboards, banners, LED displays enabling moving pictures, or even the sound...in exteriors have a crucial importance for the conspicuousness of the visual expression. In addition to good idea and large format, the consumers' attention should be paid to an unusual place where the advertisement is put. In order to achieve this, the growing trend is to place banners, posters, signs, graffiti and mural in busy, frequent places as well as in places where it is totally unexpected to find an advertisement (the advertising on buses, subways, taxicabs and trains, etc.)

The greatest advantage of outdoor advertising is in the fact that the audience cannot avoid seeing an advertisement put in a public place because it cannot be switched off as is the case when watching TV at home. The audience has to notice it, and thus it becomes the active participant in the advertisement. "It's message work on the advertising principle of "frequency." Since most messages stay in the same place for a period of a month or more, people who drive by or walk past see the same message a number of times" (Bruneau, 2009).

If we want the advertising to convey the message successfully, we have to take care that the information on the outdoor advertisement could be read in only $2 / 5$ seconds, since "ninety five percent of the time, either the message or the audience is in motion" (Bruneau, 2009). In view of that, the elements of which the advertisement is composed of have to be properly organized: the text message has to be concise, i.e. to contain the maximum of 7 words and to use a distinct typographic solution. Several words, simple background, conspicuous colours and limited use of illustrations or photographs are characteristics of a good advertisement which add up to the immediacy of a visual expression.

Regardless of the rules or methods concerning all outdoor advertising forms, the following examples will show positive and negative side of an advertisement.

Taking Guerilla marketing as an example of the most creative and most extreme form of urban advertising, we will try to point to a positive and very intelligent approach to advertising, but at the same time, we will pay attention to drawbacks of the modern marketing in Serbia.

\section{Challenging the Stereotype}

\section{Guerilla Marketing}

Guerilla marketing, with its unconventional approach to advertising, very often involves a whole viewer both by physical contact, his/her getting in touch with an advertisement and by encouraging the mental process. Therefore, such an impact leads to a unique and unforgettable experience.

The concept of Guerilla marketing is to have intelligent and creative ideas presented in unexpected places in an unexpected form. The space is very often an integral part of the visual expression since through interventions in it the idea becomes directly linked up with characteristics of an object or ambience. According to Wikipedia "Instead of money, the primary investments of marketing should be time, energy, and imagination. The objective of guerrilla marketing is to create a unique, engaging and thought-provoking concept to generate buzz, and consequently turn viral" ("Guerrilla marketing," 2010; "Startup Guide," 2008).

According to Levinson, "the Guerrilla marketeer must "deliver the goods"...In order to sell a product or a service, a company must establish a relationship with the customer. It must build trust and support. It must understand the customer's needs, and it must provide a product that delivers the promised benefits" (Levinson \& Godin, 1994). 
The use of space, 3-D interventions on objects used as integral parts of an advertisement, enlargement of everyday objects to unexpected dimensions and complete changing of the environment bring about concrete results, which is illustrated by the following examples (see Figures 4 and 5).

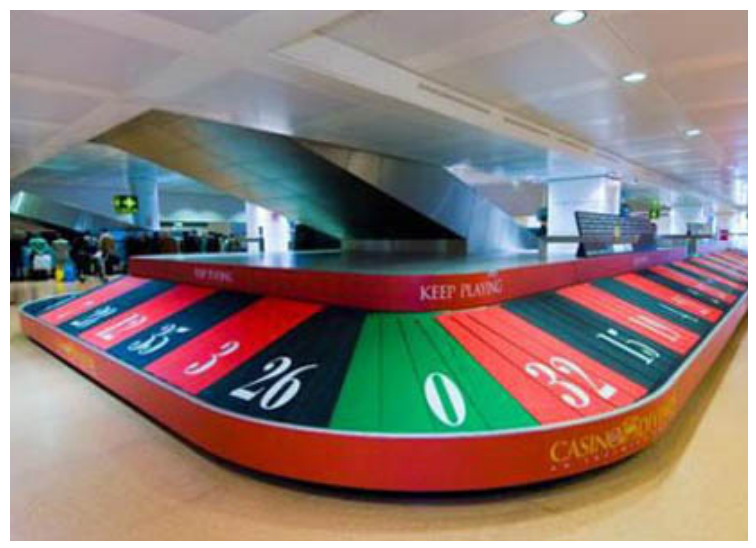

Fig.4. Casino ad in the airport

Source: http://www.funnymos.com/guerrillaadvertising.html

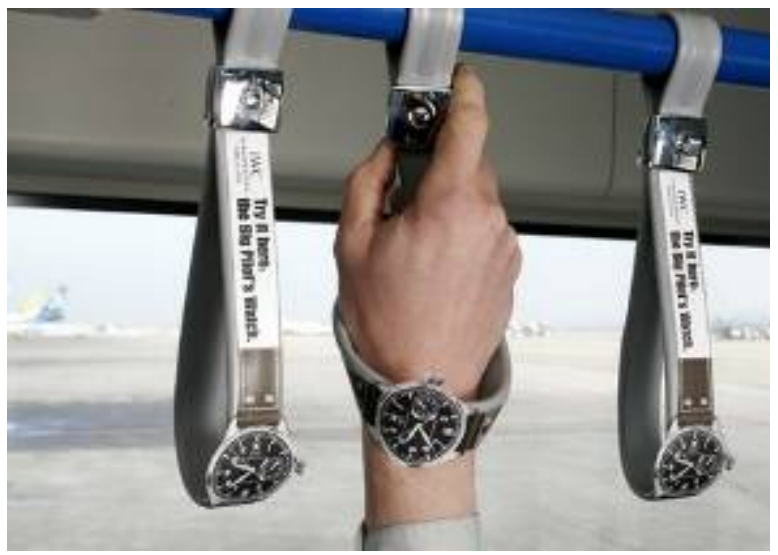

Fig.5. Watch brand ad in the bus (Try it here)

Source: http://www.funnymos.com/guerrillaadvertising.html

The following examples show the way in which the space is used in Guerilla marketing.

The principle of posting the advertisement "High in the Sky" has proved to be exceptionally provocative and eye-catching because great heights provide a better view of the environment and of the advertisement as well (see Figures 6 and7).

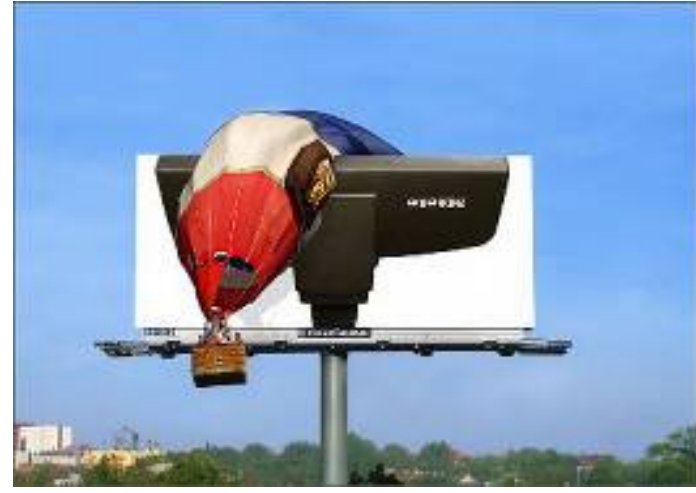

Figure.6. Vacuum cleaner ad Source: http://www.funnymos.com/guerrillaadvertising.html

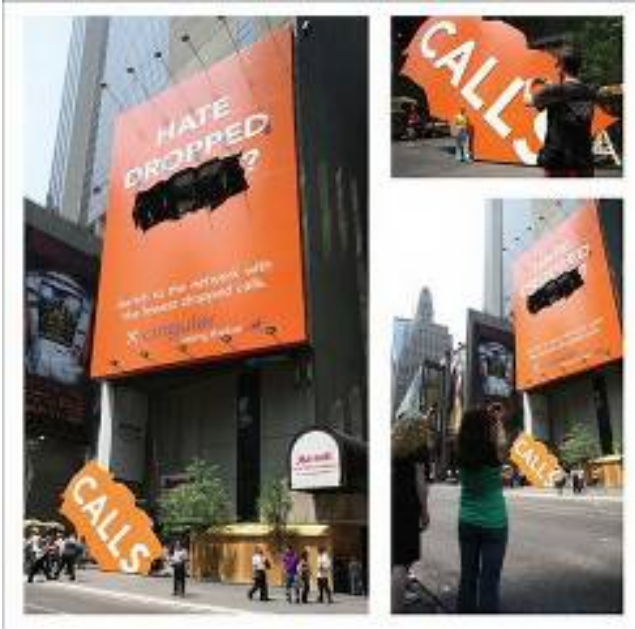

Figure.7. Inventive mobile carrier ad Source: http://www.funnymos.com/guerrillaadvertising.html

"Down on the Ground" is another way to grab pedestrians' attention by small but clever signs. Pedestrians watch where they go so they cannot but notice the message (see Figures $8 \& 9$ ). 


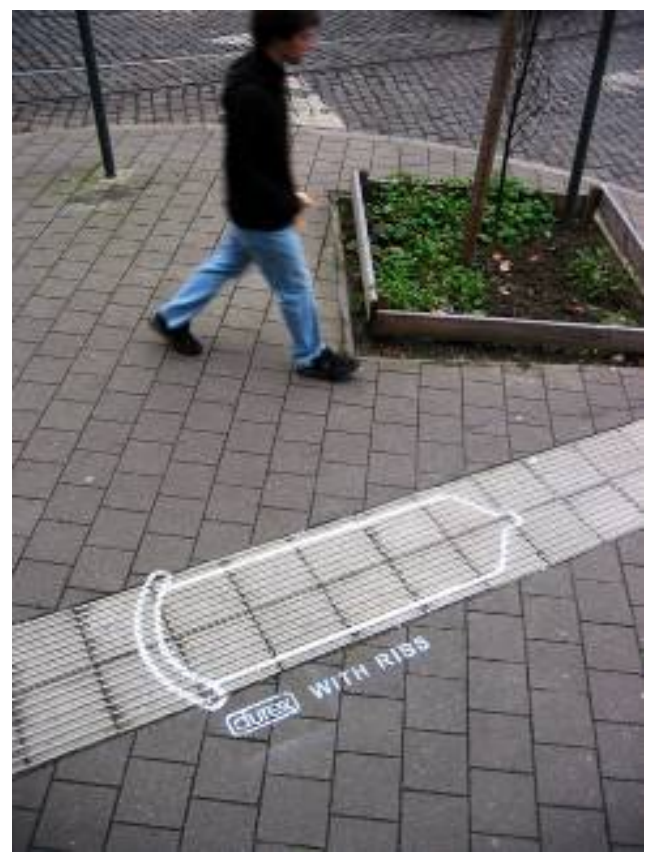

Fig. 8. Durex with ribs Source:

http://www.funnymos.com/guerrillaadvertising.html

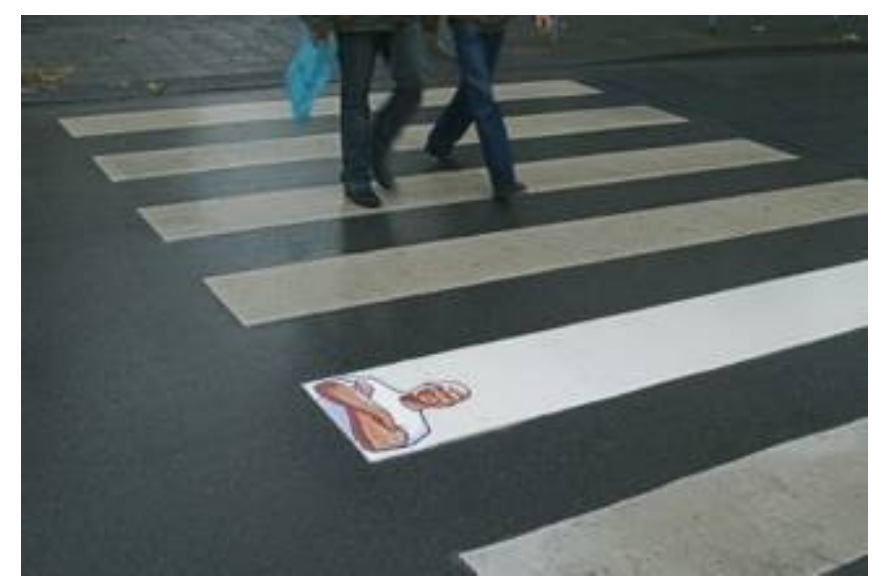

Fig. 9. Mr. Clean Crosswalk

Source: http://www.funnymos.com/guerrillaadvertising.html

"Ads on the Level" is another way to get attention by putting the advertisement at the pedestrians' eye level, so that they can see, touch and interact with them (see Figures $10 \& 11$ ).

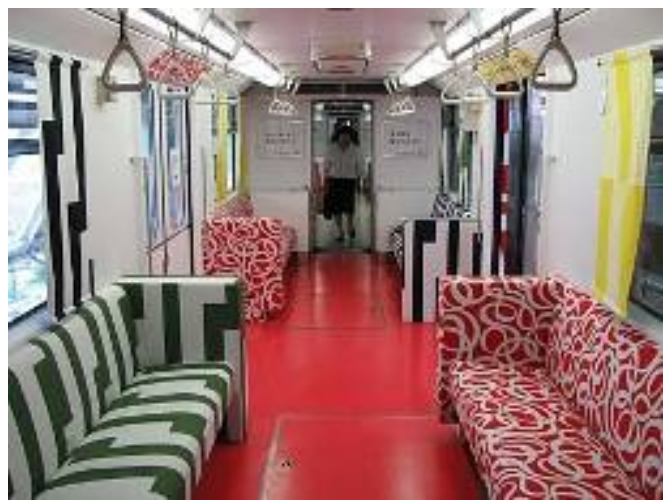

Fig. 10. Ikea Furniture on Japanese Subway Source:

http://www.thejournalmarketing.com/2008/0 4/ikea-furniture-on-japanese-subway.html

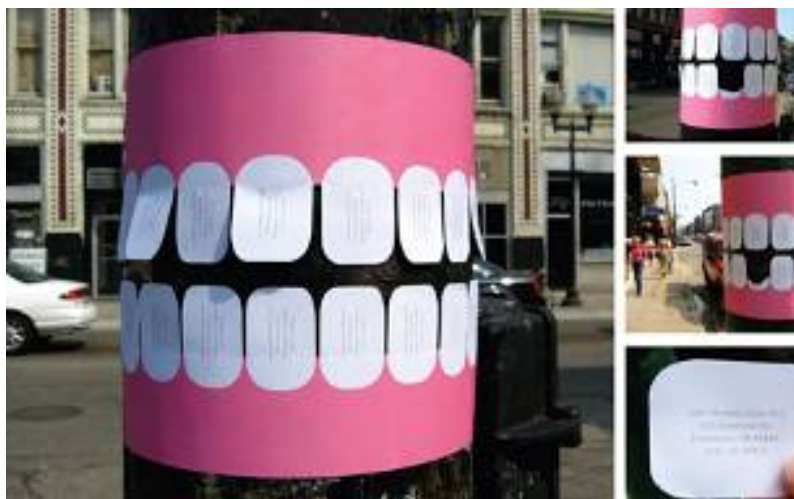

Fig. 11. The poster as a business card tear off to promote a local dentist

Source: http://enso.com.au/creative-guerrillamarketing/

The provided examples of advertising campaigns speak in favor of our opinion stating that the expression which is not stereotyped proves to be excellent means of modern advertising and it can hardly make one feel indifferent.

In view of this, we should point to the position of advertising campaigns in our home country, Serbia. 


\section{Bomb the City advertising}

As Serbia was closed for several decades suffering bad economic and political position, the access to information was restricted, which caused lagging behind the modern trends in all areas of life. Preoccupation with state problems, along with political and economic uncertainty, created the situation where state institutions and heads of these institutions very often had little understanding of creativity and freedom of expression. This especially affected the diffusion of fine art and visual communication fields of work.

Even when creative thinking found its way to be presented to the public, it did not get understanding due to low cultural and visual level of public awareness. "Culture in Serbia has been marginalized and it is at an extremely low level, which is evidenced by the fact that only a fourth of the citizens understands its meaning in everyday life." This was said at the promotion of the book of Zagorka Golubovic Culture and Transformation of Serbia - Value orientations of the citizens during the changes after 2000 ("Kultura u Srbiji," 2010).

On the other hand, a grave economic situation of our home country, "Serbia's average net salaries in February amounted to a little over EUR 300" ("Highest Salary," 2007). "For the 'average basket' of goods and services, which according to official statistics costs RSD 52,000 (EUR $1=$ RSD 103.38) . The average basket includes food and beverages, clothing, housing, water, electricity, gas, health costs, transport, communications, recreation and culture, education . However for many Serbians many of these items will be unavailable as average salaries fall far short of the cost of the 'average basket'. " "Serbia: Average Shopping Basket," 2011). "The average net salaries and wages paid in Serbia in January 2011 totaled RSD 34.009 (EUR 1=RSD 103.38), which is a 14.1 percent decrease in nominal terms and 15.3 percent decrease in real terms compared to December 2010, the Statistical Office of the Republic of Serbia" stated . ("Average salary in Serbia," 2011), hindered the presentation of creative ideas, so that the post-production, as one of the significant factors of fine art expression, was lagging behind the modern efforts. According to the research by Zagorka Golubovic published in her book Culture and Transformation of Serbia - Value orientations of the citizens during the changes after 2000 "a classification of the respondents can be made into the ones who know nothing about culture and who are manly dedicated to the "bare living", the ones in the middle who are consumers of culture and who visit museums and theatres only when they have enough money, and a small number of the ones who form a group of the "conscious", who are critically and culturally orientated." During the interview for the Blic, a daily newspaper, she added that "the culture is not comprehended as a way of living and that it is culture which gives us the direction and determines main values by which it will be developed" (“Kultura u Srbiji," 2010)

In spite of the rapid technical and technological growth during the recent years, even the art of advertising is at a very low level. Although artistic freedom and creative thinking are allowed within the art of advertising, which we pointed to in the examples of Guerilla advertising, a lower level of general education of the society in Serbia (especially of customers asking for campaigns) has posed a problem to understanding of new ideas. As said by Z. Golubovic, "the impression of the majority of citizens is that the society moves backwards and that instead of transitional evolution, there is involution." [...] "In comparison to the culture and society of the 60's and partly 70 's of the previous century, when the culture was really appreciated and was omnipresent, and when the mass culture was far more substantial, the present-day mass culture is in fact a "pink culture' which represents frivolous entertainment" ("Srbe kultura," 2010).

We made questionnaire for 50 people who are passing twice per day beside billboards which have been shown in next photos. The question, that, were they notice billboards, 25 of them sad yes, 14 sad maybe some and $11 \mathrm{sad}$ no. The question what they saw, 19 of them sad that they don't 
know, 15 sad- some hypermarket articles advertising, but didn't remember which, 5 of them notice the proper article and 11 didn't notice even billboards.

It all points to the conclusion that advertising as one of the most powerful media for generating profit did not take the first place and thus it did not develop enough.

Unconventional way of thinking, typical of advertising campaigns, is still an unreal solution for our society.

Therefore, we are of the opinion that the society should be educated gradually, and we should be getting it used to the fact that visual expression is the best medium for conveying the message (the fact is that $70 \%$ of any matter is learnt about by eyesight) and for raising the awareness of the current problems. "Pictures have always been the surest way of conveying an idea, and next in order, words that call up pictures in memory." (Lippman, 2007)

A frustrated society is skeptical of novelties, so we should be moderate and cautious when presenting a modern view of any sort or otherwise the whole process would prove to be counterproductive.

The problem of non-art, kitsch and pulp is widespread in our market largely owing to the mentioned cultural exclusion. It is an additional problem of the society which has to be dealt with. We believe that a spontaneous presentation of art, which would not be intrusive, should be a good solution to get people gradually used to novelties in visual perception. From our point of view, Guerilla advertising is certainly one of the best ways of advertising. However, we are convinced that such type of advertisement could meet with an adverse reaction and not to mention the risk of wrong interpretation of the original message. These could be the consequences of the relatively narrow views of the society.

Due to the stagnation of the cultural management that lasted for several decades, the market and customers asking for advertising campaigns mainly dictate the aesthetic values in our country. Campaigns are manifested as counter-art or non-art, in a form of mawkish direct messages that, except for presenting themselves, bear no deeper meaning.

The following examples show numerous advertising photographs that do not meet any aesthetic principles. They are packed full of textual and pictorial information, hardly readable, not at all simple, they are literal, without ideas, not thought-provoking, cannot be noticed in the space as they are put in inadequate places, cannot be viewed quickly... These factors make them unnoticed and they cannot be remembered (see Figures $12 \& 13$ ).
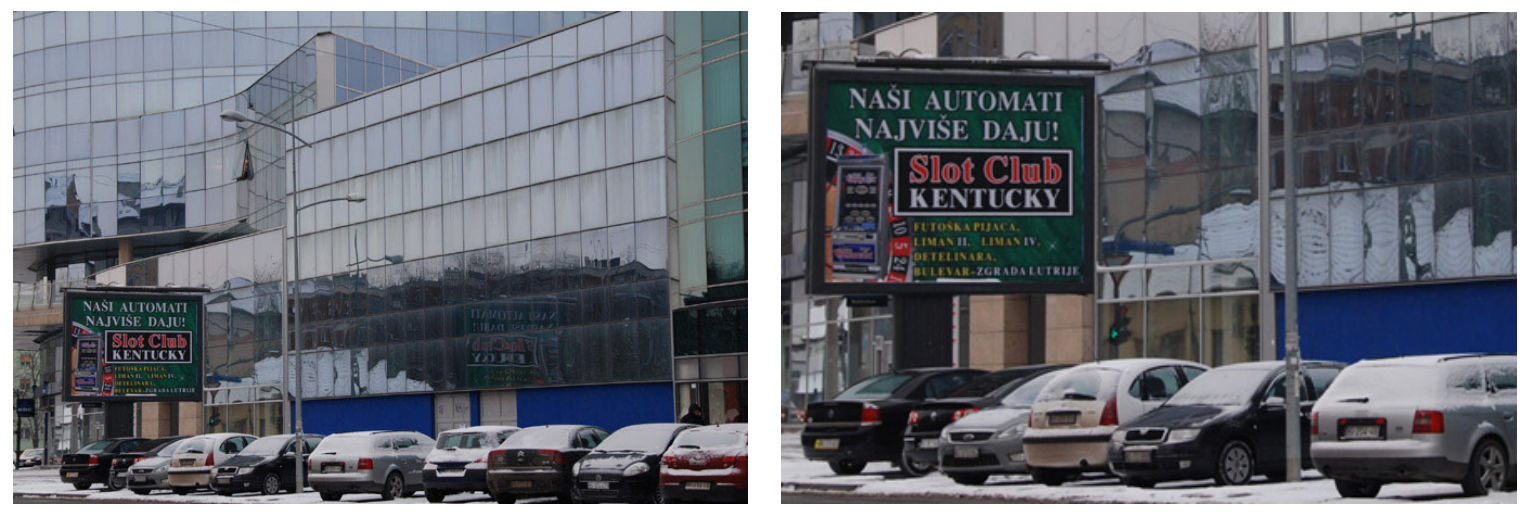

Figures $12.1 \& 12 . .2$. Hardly readable billboard full of textual information Personal photographs by authors, Novi Sad, Serbia 

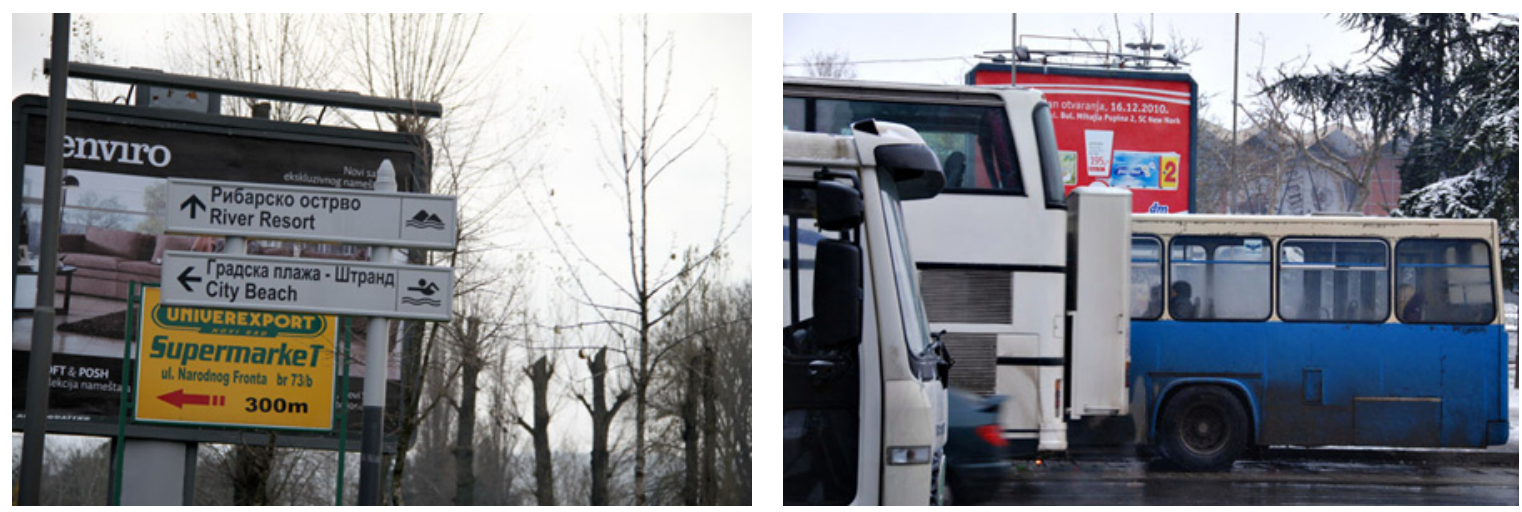

Figures $13.1 \&$ 13.2. Billboard put in inadequate place

Personal photographs by authors, Novi Sad, Serbia

There are rare examples of advertising campaigns that are found outside such a framework, but they are neither bold enough nor provocative. Owing to the limitations set by employers, marketing teams' freedom of expression is often curtailed.

As our market is flooded with not so creative visual solutions that are kept in the subconscious, we believe that it is a must to change, enhance and influence cultural needs of the society.

By the project named BOMB THE CITY ADVERTISING, we are trying to drive out the kitsch or non-art in advertising by provocation. Through interventions on billboards, as the most eyecatching and up-to-date means of advertising in the urban environment, we fight against a low level of visual education of the society.

"The goal of education is to teach an individual how to seek factual information and base reasoned conclusion on those data. Persuasion uses factual information and emotional appeals to change a person's mind and to promote a desired behavior". (Lester, 2006)

The photographs show the places where billboards are displayed and ambience they are found in. We deliberately emphasize the ambience as an important factor for presentation of the message. By the new approach, through artistic aspect, we will try to present more creative solutions which are not only a document of the product in the broadest possible meaning, but they also promote the fundamental principles of aesthetics aimed at faster accepting of information.

We will show how even an empty display could be more effective than a bad advertisement in terms of noticeability (see Figure 14).
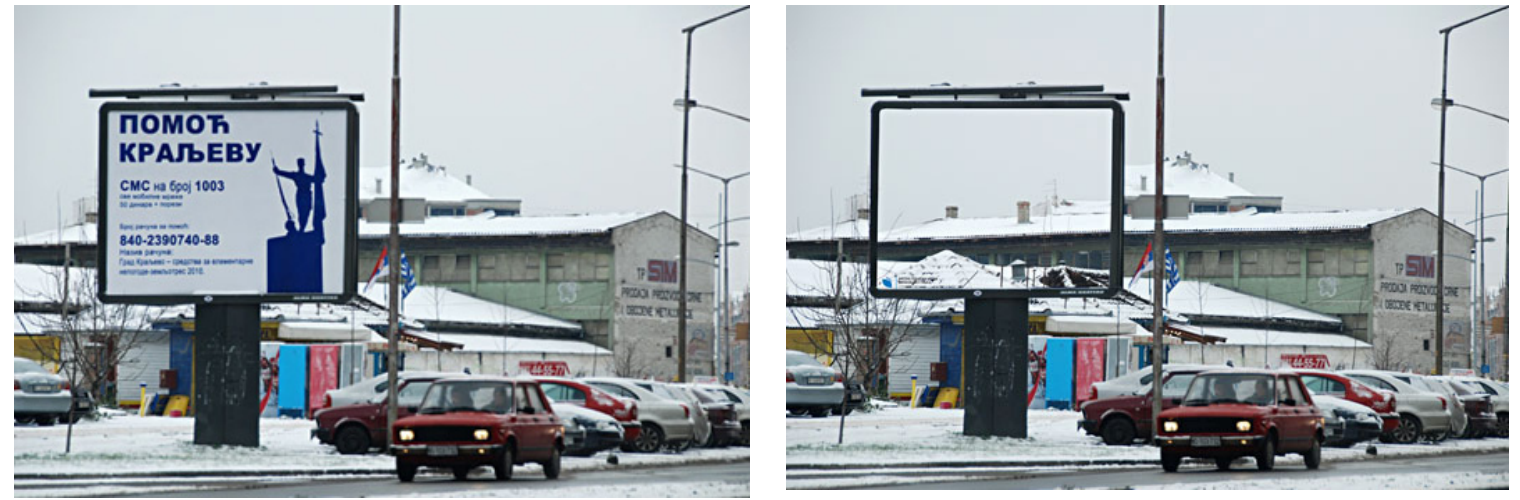

Figures $14.1 \& 14.2$. Invisible billboard through the action replace Personal work by authors, Novi Sad, Serbia 
Through the action replace, it was planned to put photographs that fit in the space by imitating it, for example to make a billboard invisible (see Figure 15).
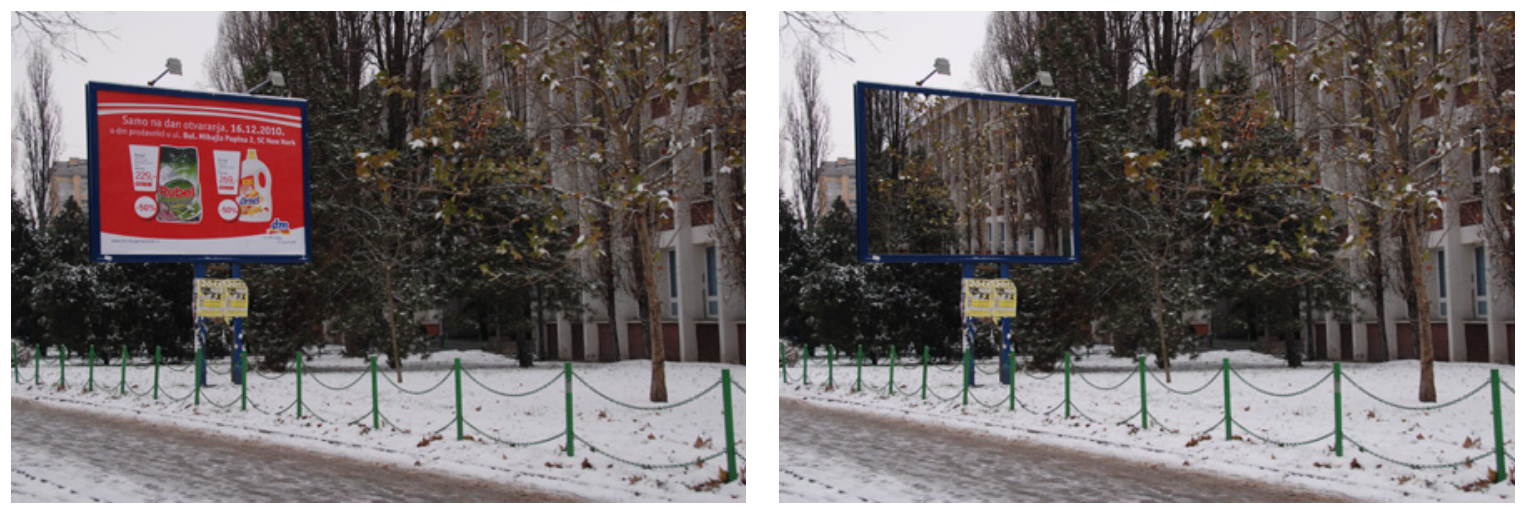

Figure $15.1 \&$ 15.2. Invisible billboard through the action replace Personal work by authors, Novi Sad, Serbia

The most frequented places in the city providing advertising space were targeted.

In any case, "empty space" or a lack of an advertisement would provoke thinking in a manner "what is being advertised". In this way, it becomes a remembered place for an advertisement. Placing a blank in the space intended for an advertisement, we symbolically show our attitude towards the modern society (see Figure 16).
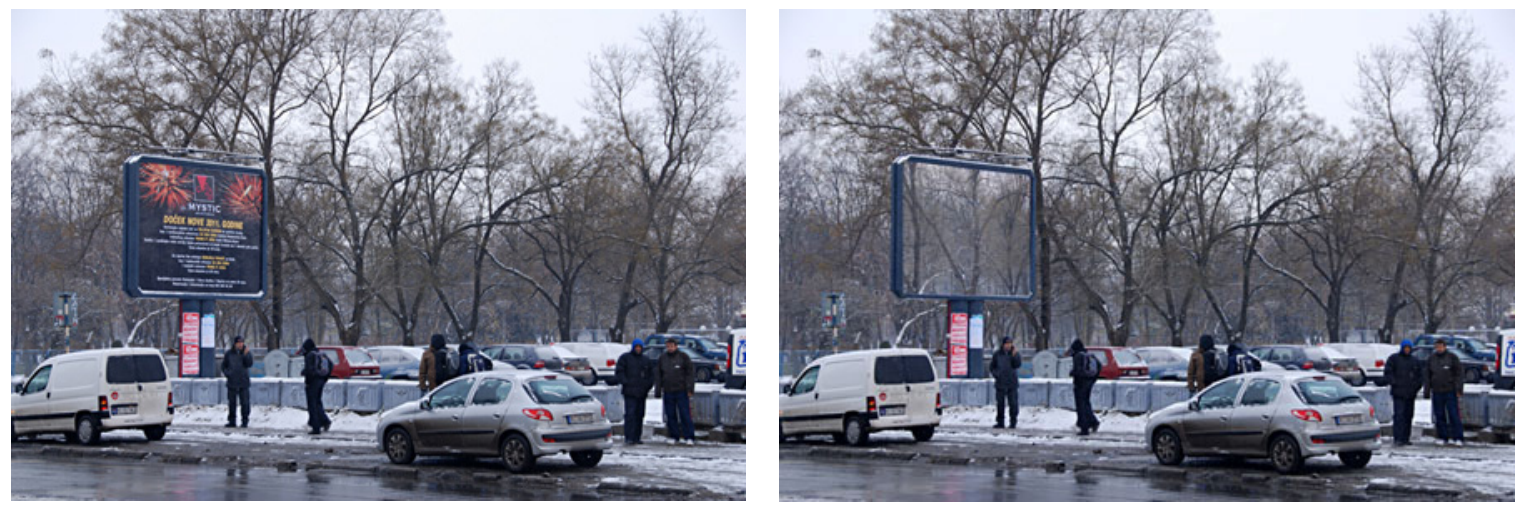

Figure $16.1 \& 16.2$. Invisible billboard through the action replace Personal work by authors, Novi Sad, Serbia

In this way the public's attention is driven to the fact that an advertisement does not have to be direct information. Also, we show how a stereotype is not the only solution.

Thus, we point to the fact that any kind of exception to the established rules brings a reaction, which should result in development of creative thinking.

The aim of our action is to remind the public that a billboard has to contain more intelligent, imaginative and inventive realizations of an idea. In addition, we would like to remind the public that the ambience surrounding a billboard is equally important because it affects its conspicuousness. 
The public has to be gradually introduced to increasingly more aggressive ways of advertising, which should be different from what a poorly educated public has been used to. In any case, the ultimate aim should certainly be to make the public enter into a dialogue.

\section{Conclusion}

The aim of this project is to remember that a gradual visual education, raising the awareness of modern ways for conveying a message within advertising and provoking the public to enter into a dialogue are the tasks of cultural management.

We took some of the most extreme examples of outdoor Guerilla marketing as indicators of the use of artistic expression for advertising purposes, as one of the possible solutions. That is an example of marketing that could be realized without substantial financial resources. It also shows that an idea is the most important factor in advertising. Over the time, such kind of advertising could become a good form of advertising in our country because of the strong need for the development of cultural awareness and because it combines art and marketing.

We believe that, except for individuals, the institutions dealing with cultural management should seriously consider the problem of the presentation of visual expression in advertising in Serbia.

Interactivity is, for now, one of the most important and best solutions to presentation of advertising message. Upon considering numerous examples of interactive advertising, it was proved that a viewer-consumer by his/her reaction becomes an active member of the advertisement. As a mere participant, he/she reacts and thus receives the message and enters into a dialogue.

We have seen the extent to which ambience, humor, social problems, creativity and challenging of stereotypes in message presentation can influence the final outcome - to remember and consume a particular product or an idea.

\section{References}

Average salary in Serbia in January totaled RSD 34.009. (2011, February27). Retrieved from http://www.emportal.rs

Bruneau, E. (2009). Outdoor advertising advantages. Retrieved from http:/www.marketingscoop.com/outdoor-advertising-advantage.htm

Dragicevic Sesic, M., \& Stojkovic, B. (2007). Kultura: memadzment, animacija, marketing [Culture: management, animation, marketing] (5th ed.). Beograd: Clio.

Giddens, E. (2005). Sociologija [Sociology]. Ekonomski fakultet Univerziteta u Beogradu, Beograd

Guerrilla marketing. (2010, November 30). Wikipedia. Retrieved from http://en.wikipedia.org/wiki/Guerrilla marketing

Highest Salary in Serbia EUR 4,940; Lowest EUR 3. (2007, April02). Retrieved from http://www.emg.rs

Kultura u Srbiji je na poražavajućem nivou [Demoralizing level of Culture in Serbia]. (2010, September14). Retrieved from http://www.srbijanet.rs/kultura/vesti/62891-kultura-u-srbiji-je-naporazavajucem-nivou.html

Lester, P. M. (2006). Visual communication: Images with messages (4th ed.). USA: Thomson Wadsworth. Levinson, J. C., \& Godin, S. (1994). The guerrilla marketing handbook. USA: Houghton Mifflin.

Lippman, W. (2007). Public opinion. USA: NuVision Publications.

Serbia: Average Shopping Basket Too Expensive. (2011, February12). Retreived from http:/www.topix.com/forum/world/serbia/TALN95OSVVG9HA9T2 
Srbe kultura ne zanima, [Serbs not interested in Culture]. (2010, September14). Retrieved from http://www.blic.rs/Kultura/Vesti/207125/Srbe-kultura-ne-zanima

Startup guide to guerrilla marketing: A simple battle plan for first-time marketeers. (2008)., Entrepreneur Media Inc, USA

\section{Biographies}

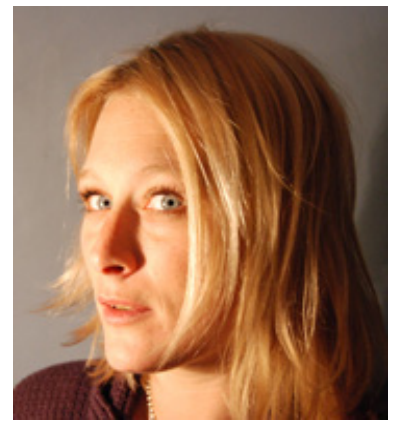

Sibila Petenji Arbutina, born 1976, is a lecturer at the Higher Technical School of Professional Education, Novi Sad, Serbia. She teaches photography courses: Applied Photography course and Theory and Visual Elements of photography. She holds a MS in Graphic Art at Academy of Art, Novi Sad. She had 10 solo and many group exhibition. Her professional fields of interests are photography, design, painting, graphic arts,drawing and multimedia art.

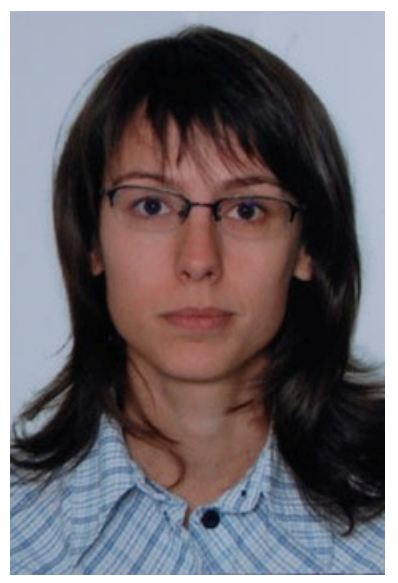

Jelena Kovačević Vorgučin, born 1975, is an assistant professor at Academy of Arts in Novi Sad, and lecturer at the Higher Technical School of Professional Education, Novi Sad, Serbia. She teaches photography courses: History and Aesthetic of Photography and Documentary Photography. She holds a MS in Photography at Faculty of Applied Arts in Belgrade. She had 8 solo and many group exhibition. Her professional fields of interests are photography, advertizing, design, and multimedia art. 